\title{
Poly A RNA
}

National Cancer Institute

\section{Source}

National Cancer Institute. Poly A RNA. NCI Thesaurus. Code C80376.

An RNA transcript that contains a tail of poly A residues at its 3' end. 